\title{
LACTIC ACID IN THE BLOOD OF RESTING MAN
}

\author{
By A. V. BOCK, D. B. DILL AND H. T. EDWARDS \\ (From the Fatigue Laboratory, Morgan Hall, Harvard University, and the Medical Labora- \\ tories of the Massachusetts General Hospital, Boston)
}

(Received for publication April 14, 1932)

The conception that, under resting conditions, blood lactic acid varies directly with $\mathrm{pH}$ is now current in the literature. According to this view, in states of alkalosis, lactic acid increases in the blood while during acidosis the opposite effect is produced. The origin of this conception is chiefly attributable to the work of Macleod (1), Anrep and Cannan (2), Long (3), and Eggleton and Evans (4). A further commonly accepted view concerning lactic acid in the blood of resting man is that this substance originates chiefly from muscle metabolism. The gradual accumulation of data in our hands from various sources during the past few years with respect to lactic acid has led to the formulation of the following inquiry: To what extent are the generally accepted mechanisms mentioned above concerning lactic acid operable in man? An investigation of these questions is desirable because much of the existing information has accrued from experimental work on cats and dogs. The present data have been obtained in a study of normal man unless otherwise stated. The methods used for preventing in vitro changes in the blood and for its analysis have been described before (5). Following the procedure we have adopted, the amount of lactic acid found in the blood of resting man has a range of 6 to $14 \mathrm{mgm}$. per $100 \mathrm{cc}$., the average value being about $10 \mathrm{mgm}$. Alkalosis has been produced by ingestion of sodium bicàrbonate or by voluntary over-ventilation. Acidosis has been produced by ammonium chloride administration. In addition, observations have been made in anoxemia, in moderate work, and on a dog during alkalosis.

\section{ALKALOSIS}

After a rest of 30 minutes in a reclining position, venous blood was secured from four normal men, and alveolar air samples were taken. The subjects then ingested 20 gram doses of sodium bicarbonate at 9 A.M., at 11A.M. and at 2 P.M. During the day the alkaline reserve ${ }^{1}$ of venous blood was determined from time to time with results as indicated in Figure 1. On the first and last samples of blood, analyses were per-

1 Alkaline reserve is defined as the carbon dioxide content of oxygenated whole blood when the partial pressure of carbon dioxide is $40 \mathrm{~mm}$. $\mathrm{Hg}$. 
formed the results of which are indicated in Table I. Corresponding data on the subject H. D. from the paper of Dennig, Talbott, Edwards and Dill (6) are included in the table, as well as similar data from a case of nephrosis in a girl, age 15, treated at the Massachusetts General Hospital for 10 days with large doses of alkali. The $\mathrm{CO}_{2}$ content of arterial blood in the latter case was 70.0 volumes per cent, of true plasma, 84.4 volumes per cent and the $\mathrm{pCO}_{2}$ was $44 \mathrm{~mm}$. of $\mathrm{Hg}$.

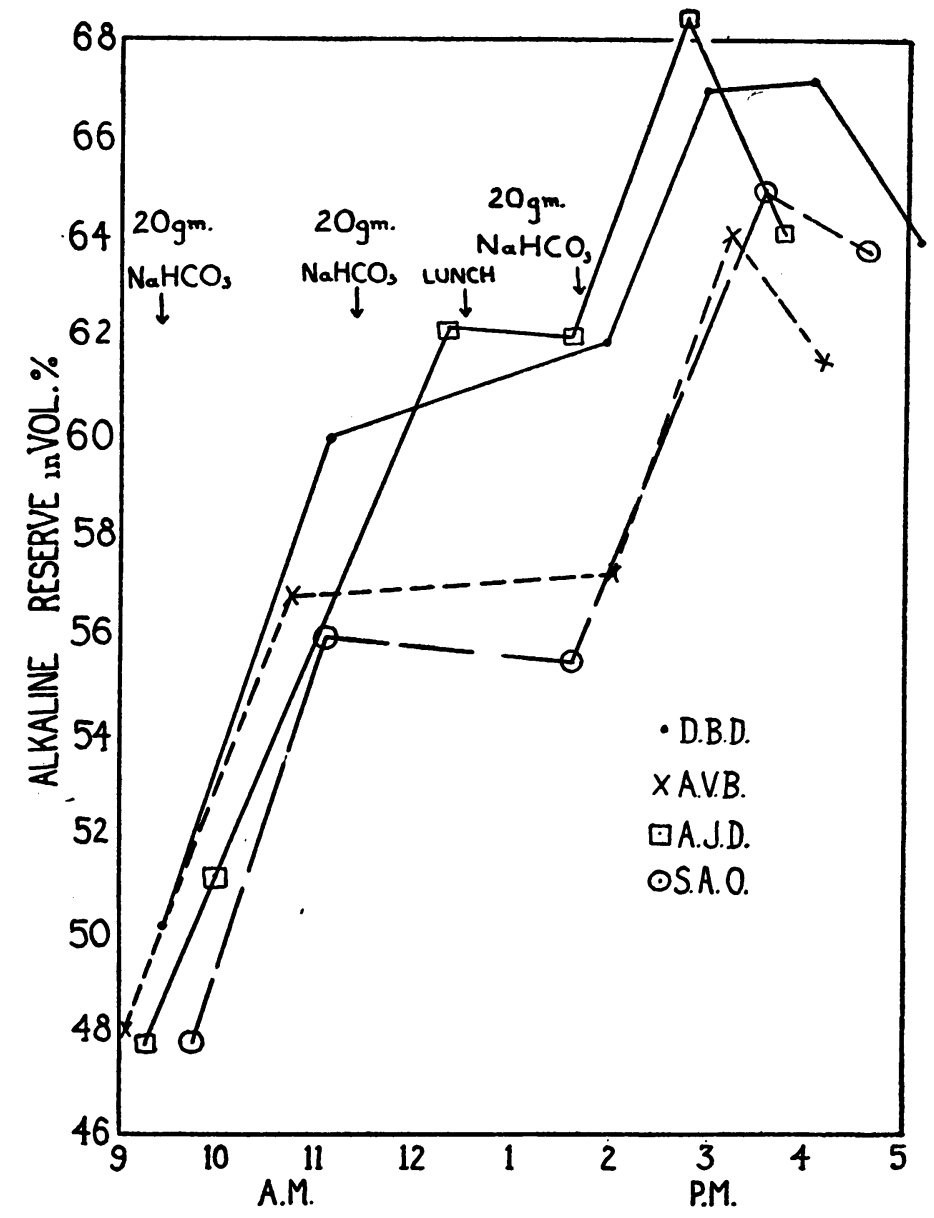

It is obvious from these data that compensated alkalosis in man is not necessarily accompanied by an increase in blood lactic acid. The $\mathrm{CO}_{2}$ content of blood may be increased by 50 per cent without change beyond the normal range in lactic acid concentration. In brief animal experiments, the use of anesthetics, artificial respiration, and operative procedures have all been followed by very high lactic acid values during alkalosis, apparently demonstrating, in the production of lactic acid, a 
TABLE I

Sodium bicarbonate experiments

\begin{tabular}{|c|c|c|c|c|c|c|}
\hline Date & Subject & Time & $\begin{array}{l}\text { Alve- } \\
\text { olar } \\
\mathrm{pCO}_{2}\end{array}$ & $\begin{array}{l}\text { Alkaline } \\
\text { reserve }\end{array}$ & $\begin{array}{c}\text { Lactic } \\
\text { acid }\end{array}$ & pHot \\
\hline & & & $\underset{H \boldsymbol{g}}{m m}$ & $\begin{array}{l}\text { volumes } \\
\text { per cent }\end{array}$ & $\begin{array}{c}\underset{m g m .}{p m .} \\
100 \mathrm{cc.}\end{array}$ & \\
\hline 1928 & $\mathrm{H}, \mathrm{D}$, Normal & & 39.6 & & 81 & 7.39 \\
\hline June 6 & H. D. After alkali & & 42.6 & 57.2 & 7.2 & 7.46 \\
\hline September 27 & H. D. After alkali & & 38.3 & 46.7 & 11.7 & 7.41 \\
\hline October 1 . & H. D. After alkali & & 40.3 & 56.1 & 12.6 & 7.47 \\
\hline $\begin{array}{c}\text { November } 13 . \\
1931\end{array}$ & I. G. Nephrotic & & & 67.2 & 8.5 & 7.53 \\
\hline September 30 . & D. B. D. Normal & 9 A.M. & 38.0 & 50.45 & 13.6 & 7.44 \\
\hline September 30 & D. B. D. After alkali & 5 P.M. & 46.7 & 64.3 & 10.5 & 7.50 \\
\hline October 2. & A. V. B. Normal & 9 A.M. & 38.0 & 47.65 & 8.2 & 7.43 \\
\hline October 2 & A. V. B. After alkali & 4 P.M. & 45.1 & 61.0 & 7.6 & 7.49 \\
\hline October 2 . & S. A. O. Normal & 10 A.M. & 39.0 & 47.8 & 9.2 & 7.42 \\
\hline October 2 . & S. A. O. After alkali & 4 P.M. & 45.0 & 63.45 & 10.3 & 7.52 \\
\hline tober 2 & A. J. D. Norma & 9 A.M. & 38.0 & 47.8 & 11.3 & 7.43 \\
\hline ober & A. J. D. After alkali & 4 P.M. & 43.4 & 64.2 & 14.6 & 7.51 \\
\hline
\end{tabular}

* See footnote 1 of text.

$\dagger$ Calculated in this and following tables from the known properties of blood and to correspond to the observed $\mathrm{pCO}_{2}$ in alveolar air.

reserve force to combat alkalosis. But even in the absence of alkalosis such experimental procedures are frequently followed by large increases in blood lactic acid. There is no substantial evidence suggesting that a similar mechanism is operative in man under any commonly found set of circumstances. ${ }^{2}$

\section{ACIDOSIS}

In a period of 48 hours two subjects ingested 35 grams of ammonium chloride. After a rest period of 30 minutes samples of alveolar air and blood were taken. The data obtained are given in Table II, together with similar data from the subject H. D. taken from Dennig's paper mentioned above. The values found for lactic acid again fall in the normal range even though the alkaline reserve may be reduced by more than 50 per cent with the $\mathrm{pH}_{\text {, reduced to }} 7.21$. The data are few but the experimental conditions are simple, the technique for the various determinations is thoroughly standardized and the results leave little question that additional observations would give similar results. It is perhaps worth

2 In the paper of Himwich, Koskoff and Nahum (7) in which high lactic acid values were found in anesthetized and decerebrated animals the authors make the following statement: "The experiments on the resting unnarcotized dog and those on the human beings have not been tabulated since they did not indicate significant changes in the lactic acid and glucose content of the blood." 
TABLE II

Ammonium chloride experiments

\begin{tabular}{|c|c|c|c|c|c|c|}
\hline Date & Subject & $\begin{array}{c}\mathrm{NH}_{4} \mathrm{Cl} \\
\text { ingested } \\
\text { in } 48 \text { hours }\end{array}$ & $\begin{array}{c}\text { Alveolar } \\
\mathrm{pCO}_{2}\end{array}$ & $\begin{array}{l}\text { Alkaline } \\
\text { reserve }\end{array}$ & $\begin{array}{l}\text { Lactic } \\
\text { acid }\end{array}$ & $\mathrm{pH}_{\text {。 }}$ \\
\hline 1928 & & grams & $m m . H g$ & $\begin{array}{l}\text { volumes } \\
\text { per cent }\end{array}$ & $\begin{array}{c}\text { mgm. } \\
\text { per } \\
100 \mathrm{cc} .\end{array}$ & \\
\hline $\begin{array}{l}\text { May } 28 \ldots \ldots \ldots \ldots \ldots \ldots \\
\text { September } 29 \ldots \ldots \ldots \ldots \ldots\end{array}$ & $\begin{array}{l}\text { H. D. } \\
\text { H. D. }\end{array}$ & $\begin{array}{l}28 \\
30\end{array}$ & $\begin{array}{l}28.8 \\
26.5\end{array}$ & $\begin{array}{l}34.7 \\
21.4\end{array}$ & $\begin{array}{l}8.1 \\
6.3\end{array}$ & $\begin{array}{l}7.38 \\
7.21\end{array}$ \\
\hline $\begin{array}{l}\text { October } 7 \ldots \ldots \ldots \ldots \ldots \ldots \\
\text { October } 7 \ldots \ldots \ldots \ldots \ldots \ldots\end{array}$ & $\begin{array}{l}\text { A. V. B. } \\
\text { S. A. O. }\end{array}$ & $\begin{array}{l}35 \\
35\end{array}$ & $\begin{array}{l}31.6 \\
31.4\end{array}$ & $\begin{array}{l}31.4 \\
33.4\end{array}$ & $\begin{array}{r}7.6 \\
10.3\end{array}$ & $\begin{array}{l}7.26 \\
7.29\end{array}$ \\
\hline
\end{tabular}

pointing out that the lactic acid concentration in the blood of normal resting men and dogs is only one per cent of all acid radicals, expressed in equivalents. Even though all this acid disappeared, the carbon dioxide dissociation curve would be raised only 2 volumes per cent.

\section{OVER-VENTILATION}

1. 60 per ceni $\mathrm{O}_{2}+\mathrm{CO}_{2}$. Long (3) found that breathing pure oxygen had no effect upon the lactic acid in the blood of man at rest. When, however, a mixture of 8 to 11 per cent of carbon dioxide and oxygen was breathed for 30 minutes lactic acid was completely removed from the blood as shown by qualitative tests with thiophene. The author records no estimations of the increased ventilation during the tests and only one $\mathrm{pH}$ determination is given showing a change from $\mathrm{pH} 7.50$ to $\mathrm{pH} 7.40$ after the subject had breathed 8 per cent $\mathrm{CO}_{2}+92$ per cent $\mathrm{O}_{2}$ for 30 minutes. Long concluded that the disappearance of lactic acid from the blood was a function of the change in hydrogen ion concentration.

In our experiments the subject rested on a bed for 30 minutes, his ventilation was determined and a sample of venous blood drawn to establish the bicarbonate content and amount of lactic acid. The subject was then enclosed in a Barach oxygen tent, the $\mathrm{CO}_{2}$ scrubber was removed, and the oxygen in the tent quickly run up to 60 per cent and maintained at this level. Ventilation could be measured at will by leading the expired air through a dry meter and again back into the tent. The values for total ventilation obtained in this way are but a rough measure of the respiratory exchange owing to the constantly changing amount of $\mathrm{CO}_{2}$ in the tent air, but they indicate well enough the general respiratory effort. The data of five experiments are included in Table III. Owing to the accumulation of $\mathrm{CO}_{2}$ in the tent, ventilation may be increased toward the end of the experiment up to 30 or 40 liters per minute. The presence of $\mathrm{CO}_{2}$ in the inspired air prevents blowing off of this gas from the body, and the change in $\mathrm{pH}$ incident to retention of 
A. V. BOCK, D. B. DILL, AND H. T. EDWARDS

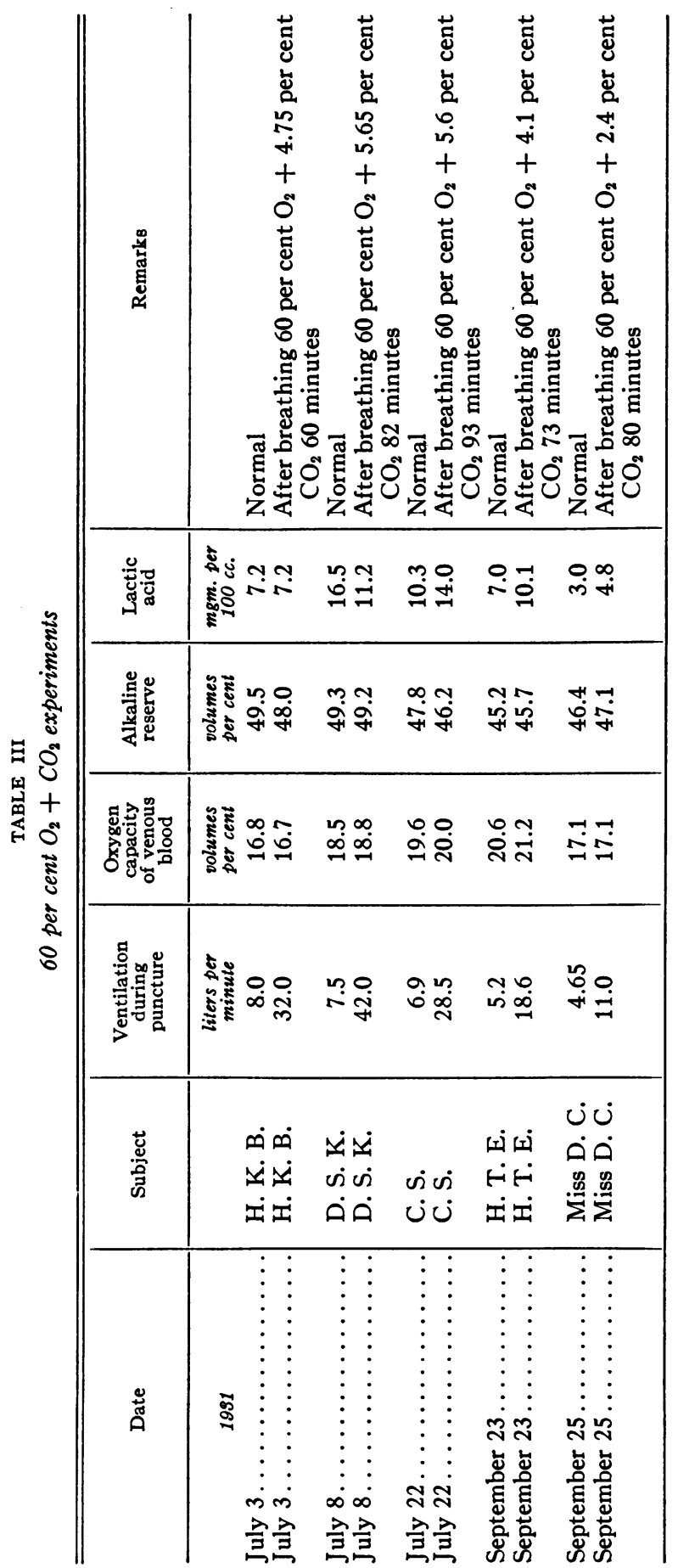


carbon dioxide is probably of the order found by Long. Since, under these conditions, we could demonstrate little if any change in blood lactic acid, the question was not pursued further. Our data do not lend support to Long's hypothesis.

2. Voluntary over-ventilation. After the usual initial period of rest on a bed the subject began voluntarily to increase his breathing. The expired air was collected in a 600-liter spirometer, an observer announced the approximate volume expired each minute and the subject attempted to maintain his volume of breathing at about 30 liters per minute. Near the end of the experiment, alveolar air samples were collected and blood drawn from both the radial artery and antecubital vein. Evidences of a state of tetany were present in every case but one when the blood was taken. The data are given in Table IV. They show that the arterial $\mathrm{CO}_{2}$ pressure ranges between 12 and $16 \mathrm{~mm}$., the arterial $\mathrm{CO}_{2}$ content is below 35 volumes per cent, the $\mathrm{pH}$, ranges from 7.60 to 7.73 and the lactic acid rises to two or three times the normal value. The duration of the experiments was too short to produce any appreciable change in alkaline reserve.

In these experiments the increase of lactic acid is associated with a high grade of alkalosis concerning which there can be no doubt, but it is to be noted that the experimental conditions are such as to interfere with the function of the greatest regulatory mechanism of the body, that of spontaneous breathing. Not only is the $\mathrm{pH}$ of the blood altered, but presumably many other variables are also grossly shifted. In the blood the primary shift occurs in the excessive elimination of carbon dioxide by the lungs and since the body is provided with protective devices of various sorts, it has been held that an increase in lactic acid during hyperventilation is a means of offsetting alkalosis. It seems clear that the increase in lactic acid is related to a complex physicochemical change which cannot be resolved with present knowledge and that therefore the explanation of the increase of lactic acid must remain uncertain. The results are quite different from those found when similar volumes of breathing per minute were induced by the simple expedient of permitting carbon dioxide to accumulate in the inspired air. In three out of five experiments in which lactic acid was determined in both arterial and venous blood there is evidence that the formation of lactic acid occurs in the muscles, but this bore no proportionate relation to the tetanic spasms and paresthesia noted by the various subjects. Such a suggestion was made by Peters, Bulger, Eisenman and Lee (8) to account for the increased organic acid found in the blood after hyperventilation.

\section{ANOXEMIA}

In addition to conditions influencing primarily the acid-base equilibrium, lack of oxygen is usually considered as the principal cause of an 


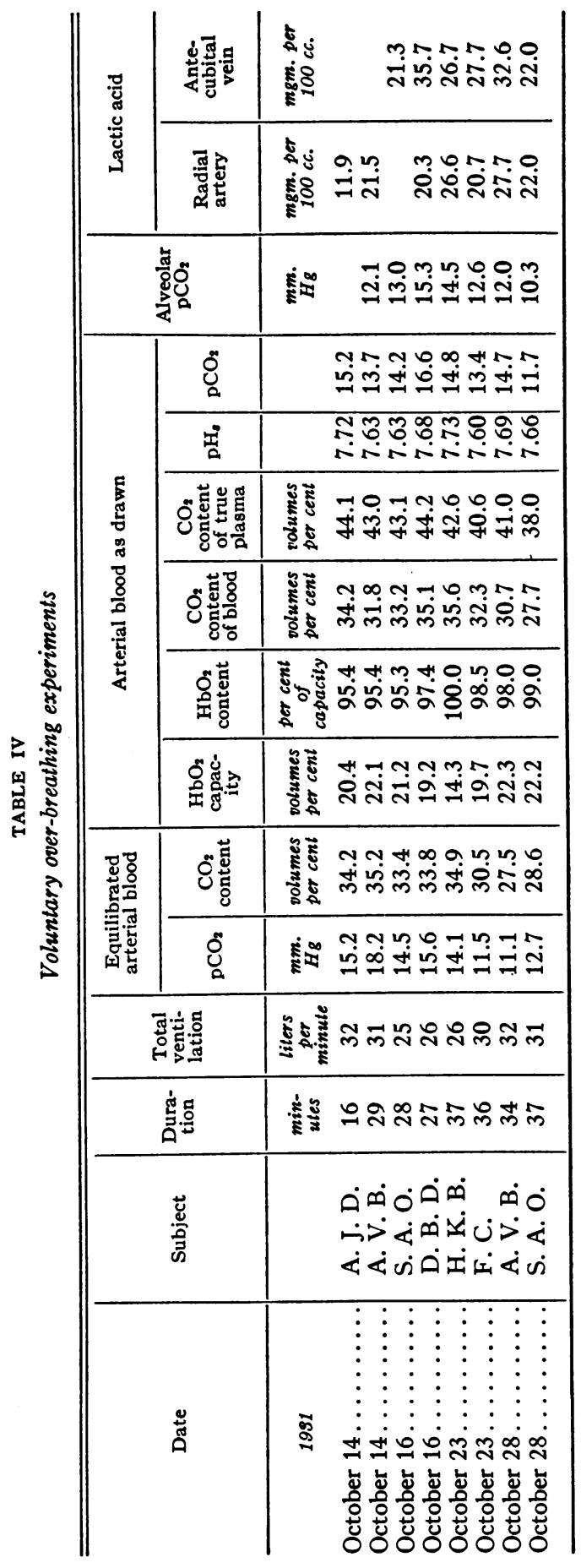


increase in blood lactic acid. The highest values for lactic acid in blood have been those found during or after severe physical exercise, in which either the supply of oxygen is inadequate or the rate of formation of this acid exceeds the speed of its resynthesis or removal independent of the oxygen supply. Notwithstanding the fact that anoxemia is constantly mentioned as a cause of increased amounts of lactic acid in the blood, there is little evidence to show at what level of anoxemia this occurs in resting man. Koehler, Behneman, Benell, and Loevenhart (9) have shown that acidosis is the terminal condition in pigs, when these animals are subjected for a sufficient period to atmospheres of oxygen as low as 4 or 5 per cent. Macleod (10) found an increase in lactic acid in animals subjected to severe anoxemia and shock, but the operative conditions were probably of vital importance in his results. Meakins and Long (11), Jervell (12) and Groag and Schwarz (13) have reported increases in lactic acid in the blood of patients suffering from congestive heart failure more or less proportionate to the degree of circulatory failure. Weiss (14) has been unable to confirm the latter results. His data indicate that lactic acid seldom exceeds $20 \mathrm{mgm}$. in patients suffering from congestive failure. Many other conditions such as anesthesia, hemorrhage, diseases of the liver, etc., are associated with abnormal amounts of lactic acid in the blood, all presumably related in one way or another to oxygen deficiency.

TABLE V

Anoxemia experiments

\begin{tabular}{|c|c|c|c|c|c|c|}
\hline Date & Subject & Inspired gas & \begin{tabular}{|} 
Dura- \\
tion
\end{tabular} & $\begin{array}{c}\mathrm{HbO}_{2} \\
\text { content } \\
\text { of } \\
\text { arterial } \\
\text { blood }\end{array}$ & $\begin{array}{c}\text { Lac- } \\
\text { tic } \\
\text { acid }\end{array}$ & $\mathrm{pH}_{\mathbf{s}}$ \\
\hline 1991 & & & $\mid \begin{array}{l}\min - \\
\text { utes }\end{array}$ & $\begin{array}{c}\text { per cent } \\
\text { of ca- } \\
\text { pacity }\end{array}$ & $\begin{array}{c}\text { mgm. } \\
\text { per } \\
100 \\
c c .\end{array}$ & \\
\hline May 1 & D. B. D. & 9 per cent $\mathrm{O}_{2}+\mathrm{N}_{2}$ & 52 & 56.2 & 12.0 & 7.49 \\
\hline May 22 & D. B. D. & 9 per cent $\mathrm{O}_{2}+2.47$ per cent $\mathrm{CO}_{2}+\mathrm{N}_{2}$ & 67 & 69.8 & 9.7 & 7.42 \\
\hline May 27 & A. V. B. & 9.1 per cent $\mathrm{O}_{2}+\mathrm{N}_{2}$ & 72 & 64.3 & $\mid 12.8$ & 7.45 \\
\hline June 2 & A. V. B. & 9.2 per cent $\mathrm{O}_{2}+2.5$ per cent $\mathrm{CO}_{2}+\mathrm{N}_{2}$ & 58 & 75.0 & 10.4 & 7.41 \\
\hline June 10 & H. T. E. & 9.2 per cent $\mathrm{O}_{2}+2.7$ per cent $\mathrm{CO}_{2}+\mathrm{N}_{2}$ & 43 & 76.9 & $\mid 12.0$ & 7.45 \\
\hline June 16 & H. T. E. & 9.2 per cent $\mathrm{O}_{2}+\mathrm{N}_{2}$ & 68 & 51.1 & 15.5 & 7.45 \\
\hline
\end{tabular}

In connection with another research not yet published we have obtained the data shown in Table V. The subjects, while sitting in a chair, breathed in one case an atmosphere of 9 per cent oxygen +91 per cent nitrogen and in another case a gas mixture consisting of 9 per cent oxygen +2.5 per cent carbon dioxide +88.5 per cent nitrogen. Nine per cent oxygen at sea level is equivalent to the partial pressure of this gas at an altitude of 22,000 feet. The degree of anoxemia reached in these experiments, as shown by the per cent saturation of arterial blood with oxygen, 
equals or exceeds that found in most cases of lobar pneumonia or of circulatory failure. The lactic acid values found are on the average about $2 \mathrm{mgm}$. higher than the average normal value. Such results suggest that anoxemia per se in man must be of a very high order of magnitude if it is to cause a substantial increase in lactic acid. Lactic acid formation is shown to be little affected when the partial pressure of oxygen in arterial blood drops to half normal. Of course it is possible that in some pathological conditions there may be not only decreased saturation of arterial blood but also a slower rate of movement of blood through the capillary bed. When this occurs the mean pressure of oxygen will be further reduced.

\section{MODERATE PHYSICAL EXERCISE}

Although the response of the body during physical exercise is not of primary interest in this paper, the data of experiments tabulated in Table VI are included to demonstrate the stability of lactic acid concentration

TABLE VI

Exercise experiments of 30 minutes' duration

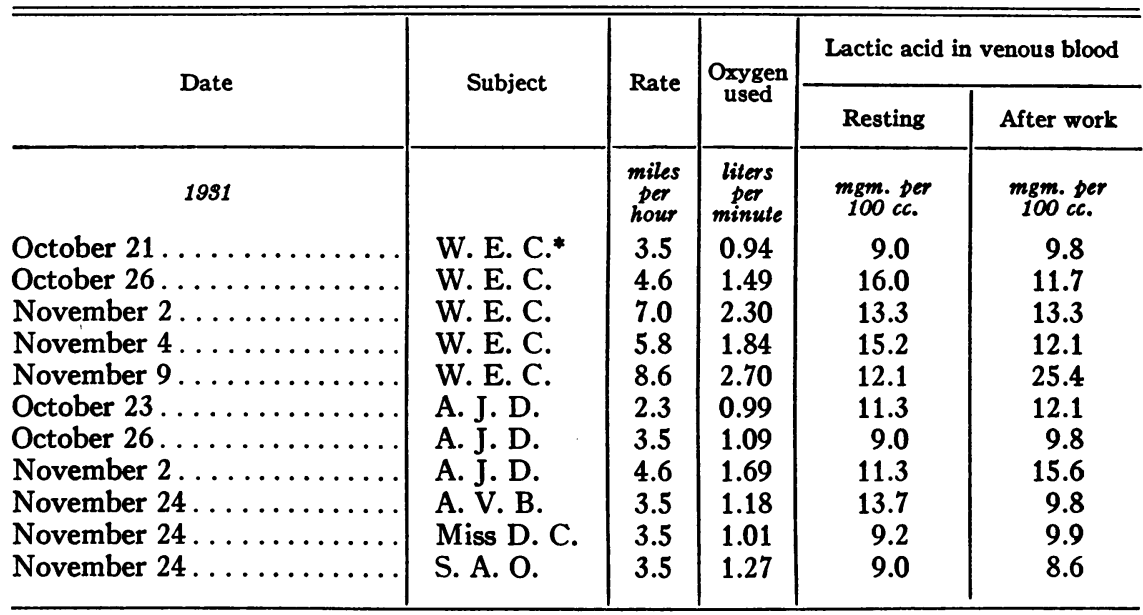

* Trained runner.

even during exercise requiring a metabolic rate several times that of the resting state. The subjects walked or ran for 30 minutes on an electrically driven treadmill at the speeds indicated in the table. The only subject in physical training was W. E. C. The results are significant, especially when account is taken of the conception that the lactic acid present in the blood during rest has its origin in the muscles. These experiments appear by contrast to exclude such possible sources for lactic acid during the resting state as the activity of the accessory muscles of respiration, sporadic movements of the body commonly observed in subjects lying at rest, tetanic spasms, etc. An untrained subject may by exercise in- 
crease his metabolic rate four or five times without altering his blood lactic acid. The duration of the walking tests was adequate to permit an even distribution of lactic acid throughout the body and thus raise the level of lactic acid in the blood if an overflow had occurred from the exercised muscles. The evidence suggests that resynthesis or removal of lactic acid had kept pace with its production.

\section{DISCUSSION}

From the data given above it is clear that lactic acid concentration in resting man is, relatively speaking, stable, and is not greatly influenced by mechanisms formerly considered operative. The only circumstance found in this study in which the normal resting level of lactic acid is disturbed is that of voluntary over-breathing. This fact gains in significance because the experimental conditions involved were the only ones in which there was any voluntary interference with normal regulatory mechanisms of the body. Eggleton and Evans (4) stress the importance of avoiding over-ventilation in experiments in which variations in the lactic acid content of the blood are being studied. In man there is evidence on every hand that spontaneous breathing is capable of reacting to changes occurring in the internal environment in a manner to prevent shifts of state inimical to the organism until extreme conditions are met.

Early experiments of Macleod and Hoover (15) showed that lactic acid was increased in the blood when alkaline-dextrose solutions were given intravenously. No increase in lactic acid occurred when dextrose was injected in acid solution. The animals were anesthetized and had the vena cava and portal vein exposed. In view of these results Macleod and Knapp ( $1 b)$ suggested that lactic acid may act as an acid reserve useful in counteracting alkalosis. They found that intravenous injections of solutions of sodium carbonate and sodium bicarbonate in rabbits and dogs caused an increased output of lactic acid in the urine, and that this might occur without change in the $\mathrm{pH}$ of the blood. The same result was obtained when alkali was fed to two cats and three normal men. Jervell (12) found that ingestion of bicarbonate by seven patients was followed by a decrease in concentration of lactic acid in the blood of five of the subjects. In another series of observations made on the urine of other subjects he found increased excretion of lactic acid following bicarbonate ingestion.

In order to determine the extent of variations in lactic acid concentration that may be induced in a normal dog after bicarbonate administration the following experiment was done. A mongrel dog weighing 13 kilograms was given sodium bicarbonate in 10 per cent solution, by means of a stomach tube as indicated in Table VII. In all, $848 \mathrm{cc}$. of bicarbonate solution were given in the course of three and one-half hours. During this time approximately $300 \mathrm{cc}$. were vomited and two fluid 
TABLE VII

Response of a dog to alkali administration

( $\mathrm{NaHCO}_{3}$ given in 10 per cent solution by stomach tube. Weight of dog, $\left.13 \mathrm{kgm}.\right)$

\begin{tabular}{|c|c|c|c|c|c|c|c|c|c|}
\hline \multirow[b]{2}{*}{ Time } & \multirow[b]{2}{*}{ Remarks } & \multirow[b]{2}{*}{$\begin{array}{l}\text { Rectal } \\
\text { temper- } \\
\text { ature }\end{array}$} & \multicolumn{7}{|c|}{ Observations on venous blood } \\
\hline & & & $\underset{\text { ity }}{\mathrm{HbO}_{2}}$ & $\begin{array}{l}\mathrm{CO}_{2} \\
\text { con- } \\
\text { tent }\end{array}$ & $\begin{array}{l}\text { Alka- } \\
\text { line } \\
\text { reserve }\end{array}$ & $\begin{array}{c}\mathrm{pCO}_{2} \text { of } \\
\text { blood } \\
\text { as } \\
\text { drawn }\end{array}$ & $\begin{array}{c}\mathrm{pH}, \text { of } \\
\text { blood } \\
\text { as } \\
\text { drawn }\end{array}$ & $\begin{array}{l}\mathrm{pH}_{\text {, of }} \\
\text { blood at } \\
\mathrm{pCO}_{2} \\
40 \mathrm{~mm} \text {. }\end{array}$ & $\begin{array}{l}\text { Lactic } \\
\text { acid } \\
\text { blood } \\
\text { as } \\
\text { drawn }\end{array}$ \\
\hline & & $\cdot F$. & $\begin{array}{c}\text { vol. } \\
\text { umes } \\
\text { per cent }\end{array}$ & $\begin{array}{c}\text { ool- } \\
\text { umes } \\
\text { per cent }\end{array}$ & $\begin{array}{c}\text { vol- } \\
\text { umes } \\
\text { per cent }\end{array}$ & $\operatorname{mm}_{\boldsymbol{H}}$ & & & 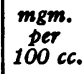 \\
\hline $\begin{array}{l}\text { 12:00 M. } \\
\text { 12:05 P.M. } \\
\text { 12:18 P.M. } \\
\text { 12:20 P.M. }\end{array}$ & $\begin{array}{l}100 \mathrm{cc} \text {. alkali } \\
125 \mathrm{cc} \text {. alkali } \\
60 \mathrm{cc} \text {. vomitus }\end{array}$ & 101.8 & 21.5 & 43.8 & 39.2 & 50.2 & 7.25 & 7.31 & 17.4 \\
\hline $\begin{array}{l}\text { 12:23 P.M. } \\
\text { 12:45 P.M. }\end{array}$ & & $\begin{array}{l}101.9 \\
102.5\end{array}$ & $\begin{array}{l}22.0 \\
22.5\end{array}$ & $\begin{array}{l}48.6 \\
53.9\end{array}$ & $\begin{array}{l}45.2 \\
50.4\end{array}$ & $\begin{array}{l}47.1 \\
47.6\end{array}$ & $\begin{array}{l}7.33 \\
7.38\end{array}$ & $\begin{array}{l}7.38 \\
7.44\end{array}$ & 24.5 \\
\hline $\begin{array}{l}\text { 1:01 P.M. } \\
\text { 1:10 P.M. }\end{array}$ & $\begin{array}{l}125 \mathrm{cc} \text {. alkali } \\
50 \mathrm{cc} \text {. vomitus }\end{array}$ & & & & & & & & \\
\hline $\begin{array}{l}\text { 1:23 P.M. } \\
\text { 1:37 P.M. } \\
\text { 1:43 P.M. } \\
\text { 1:54 P.M. } \\
\text { 2:10 P.M. } \\
\text { 2:15 P.M. }\end{array}$ & $\begin{array}{l}125 \mathrm{cc} \text {. alkali } \\
25 \mathrm{cc} \text {. vomitus } \\
\text { Fluid stool } \\
125 \mathrm{cc} \text {. alkali } \\
25 \mathrm{cc} \text {. vomitus }\end{array}$ & 102.2 & 22.8 & 63.7 & 56.9 & 54.0 & 7.40 & 7.50 & 22.5 \\
\hline $\begin{array}{l}\text { 2:20 P.M. } \\
\text { 2:58 P.M. } \\
\text { 3:02 P.M. }\end{array}$ & $\begin{array}{l}128 \text { cc. alkali } \\
125 \text { cc. vomitus }\end{array}$ & 101.9 & 26.1 & 68.2 & 58.4 & 57.0 & 7.42 & 7.52 & 33.6 \\
\hline $\begin{array}{l}\text { 3:14 P.M. } \\
\text { 3:35 P.M. } \\
\text { 3:48 P.M. }\end{array}$ & $\begin{array}{l}120 \text { cc. alkali } \\
\text { Fluid stool }\end{array}$ & 101.7 & 26.4 & 69.4 & 63.0 & 51.5 & 7.48 & 7.56 & 43.1 \\
\hline 3:55 P.M. & & 100.8 & 28.2 & 69.8 & 57.8 & 61.0 & 7.40 & 7.53 & 47.4 \\
\hline
\end{tabular}

stools were passed. For the last hour the animal appeared sick and was unwilling to stand. By the following morning he was apparently in normal condition. The initial resting value for lactic acid, $17.4 \mathrm{mgm}$., was somewhat high and showed comparatively little tendency to change after the animal had had 35 grams of bicarbonate, equivalent to three times the dose given to normal men as noted in Table I. The shift in $\mathrm{pH}$, toward the alkaline side during this time was about 0.2. Subsequently, as more alkali was given, lactic acid contentration increased rapidly. There was little further change in $\mathrm{pH}$, or in $\mathrm{CO}_{2}$ content of the blood. The condition of the animal was no longer good. The data indicate that this dog could be subjected to a dose of alkali three times greater than that given to a normal man without exhibiting any great change in lactic acid concentration, notwithstanding a change in $\mathrm{pH}$, of approximately 0.2 .

Our data as a whole indicate that the lactate content of the blood is not readily altered during alkalosis, and we conclude that any mechanism 
by means of which such an event might be brought about is of little significance in man, normally or pathologically.

Moderate acidosis produced by the use of ammonium chloride has no effect on blood lactic acid. In extreme states of acidosis following anoxemia, such as those produced in pigs by Koehler, et al. (9), great increases in lactic acid may occur, but are of little significance in the present discussion since they represent but one measurable aspect of the dissolution of the whole body.

In anoxemia Macleod (10) found an increase in lactate concentration when the respiratory mixture breathed by his anesthetized animals contained 4 to 8 per cent of oxygen, the oxygen pressures being similar to those used by Koehler, et al. Macleod suggested that the excess of lactic acid may be formed to neutralize the excess base resulting from blowing off of carbon dioxide from the blood. We find difficulty in accepting such an hypothesis without qualification in view of our results under conditions of anoxemia representing the limit to which normal men can be subjected for a period of one hour. In these experiments no compensatory mechanism involving lactic acid is evident. The data suggest that anoxemia in various clinical conditions must reach a grave state to disturb lactic acid concentration in the body. In corroboration, Jervell found in short experiments on men, while breathing low oxygen mixtures, no increase in lactic acid until the oxygen breathed was reduced to 7.5 per cent. A further consideration of this question will be published later.

There appears to be little doubt that lactic acid, in the form of a salt, is a normal constituent of blood. Some question may be raised as to the exact amount of it in a given blood sample, since the method used for its measurement may include sulphite-binding products which result from the oxidation of substances other than lactic acid. Long (3) roughly estimated the amount of lactic acid in blood by the thiophene test and compared the values obtained with those given by Clausen's method (16). He concluded that one-half to three-quarters of the yield given by the latter method was due to lactic acid itself. However, the modification of the Clausen method, since introduced by Friedemann, Cotonio and Shaffer (17), has reduced the number of interfering substances, and according to these authors has made the method more nearly specific for lactic acid. As a result, the value now obtained for lactic acid in blood during rest is approximately one-half that given by the Clausen technique. Until further work is done we may assume that the concentration found for lactic acid by the present method represents this substance.

Owing to the importance of the rôle of lactic acid in muscular contraction, as indicated in the work of Meyerhof and Hill (now modified (18)), activity of muscle, whether under working or resting conditions, is com- 
monly regarded as the source of lactic acid in the blood. Severe physical exercise in untrained men is accompanied by a large increase in lactic acid concentration, but in the case of trained individuals the same grade of exercise may produce no appreciable change in lactic acid. Moderate exercise, as our experiments and those of Owles (19) show, may be carried on with little or no alteration in blood lactic acid. Whether or not lactic acid concentration in blood increases under given conditions of exercise depends not only upon an adequate oxygen supply but presumably also upon the speed of its production.

If moderate muscular exercise in untrained men can be executed without appreciable change in the level of blood lactic acid, it appears improbable that the lactic acid formed during resting states has its origin only in muscle metabolism. The rôle now assigned to lactic acid in muscle activity (18) has no bearing on the subject. Taking into account the relative stability of lactic acid concentration during rest, it seems better not to attempt a specific explanation but to go no further than to regard this phenomenon as a part of the general process of metabolism as a whole. We suggest, for example, that it may be a split product in the oxidation of carbohydrate, mobilized for the maintenance of general body needs. Much work with reference to glucose oxidation must be done before the question can be settled. Of the lactic acid present in the blood of a resting subject a small portion may come from muscle activity, the rest presumably from the activity of the central nervous system, various glandular activities, etc. It seems logical to suppose that the ability to reconvert lactic acid to its precursor may vary greatly at the seat of its formation, just as the rate of utilization of oxygen may vary from organ to organ in the body. The problem remains for study along lines differing from those suggested in the past. An excellent review of the literature concerning lactic acid has been published recently by Himwich (20)

\section{SUMMARY}

It has been shown that lactic acid concentration in the blood of a resting man is not related simply to shifts in hydrogen ion concentration. Anoxemia is not accompanied by increasing amounts of lactic acid until extreme conditions are met. Evidence is given indicating that of the total lactic acid found in the blood under resting conditions, only a part may originate from muscle activity. No definite evidence is at hand to indicate the source of the remainder, but it is suggested that it may be a split product of carbohydrate mobilized for the maintenance of the general metabolism of the body.

\section{BIBLIOGRAPHY}

1. a. Macleod, J. J. R., Am. J. Physiol., 1917-1918, xlv, 539. Further Observations on the Production of Lactic Acid Following Alkaline Injections. 
b. Macleod, J. J. R., and Knapp, H. J., Am. J. Physiol., 1918, xlvii, 189. The Influence of Alkali Administration on the Urinary Excretion of Lactic Acid, and the Possible Significance of the Latter in Maintaining Neutrality in the Body.

2. Anrep, G. V., and Cannan, R. K., J. Physiol., 1923-1924, lviii, 244. The Concentration of Lactic Acid in the Blood in Experimental Alkalaemia and Acidaemia.

3. Long, C. N. H., J. Physiol., 1923-1924, lviii, 455. The Lactic Acid in the Blood of a Resting Man.

4. Eggleton, M. G., and Evans, C. L., J. Physiol., 1930, 1xx, 261. Lactic Acid Formation and Removal with Change of Blood Reaction.

5. Myerson, A., Loman, J., Edwards, H. T., and Dill, D. B., Am. J. Physiol., 1931, xcviii, 373. The Composition of the Blood in the Artery, in the Internal Jugular Vein and in the Femoral Vein during Oxygen Want.

6. Dennig, H., Talbott, J. H., Edwards, H. T., and Dill, D. B., J. Clin. Invest., 1931, ix, 601. Effect of Acidosis and Alkalosis upon Capacity for Work.

7. Himwich, H. E., Koskoff, Y. D., and Nahum, L. H., J. Biol. Chem., 19291930, lxxxv, 571. Studies in Carbohydrate Metabolism. I. A Glucose-Lactic Acid Cycle Involving Muscle and Liver.

8. Peters, J. P., Bulger, H. A., Eisenman, A. J., and Lee, C., J. Biol. Chem., 1926, lxvii, 175. Total Acid-Base Equilibrium in Health and Disease. IV. The Effects of Stasis, Exercise, Hyperpnea and Anoxemia; and the Causes of Tetany.

9. Koehler, A. E., Behneman, H. M. F., Benell, O. E., and Loevenhart, A. S., Am. J. Physiol., 1925, lxxiv, 590. The Cause of Death from Anoxemia.

10. Macleod, J. J. R., Am. J. Physiol., 1921, lv, 184. The Concentration of Lactic Acid in the Blood in Anoxemia and Shock.

11. Meakins, J., and Long, C. N. H., J. Clin. Invest., 1927, iv, 273. Oxygen Consumption, Oxygen Debt, and Lactic Acid in Circulatory Failure.

12. Jervell, O., Acta med. Skandinav., 1928, Supp. xxiv. Investigation of the Concentration of Lactic Acid in Blood and Urine under Physiologic and Pathologic Conditions.

13. Groag, B., and Schwarz, H., Arch. f. exp. Path. u. Pharmakol., 1927, cxxi, 23. Der einfluss der muskelarbeit auf die Blutmilchsäure, Alkalireserve, Azidität des Harns usw. bei Kreislaufkranken.

14. Weiss, Soma. Personal Communication.

15. Macleod, J. J. R., and Hoover, D. H., Am. J. Physiol., 1916-1917, xlii, 460. Studies in Experimental Glycosuria. XII. Lactic Acid Production in the Blood Following the Injection of Alkaline Solutions of Dextrose or of Alkaline Solutions Alone.

16. Clausen, S. W., J. Biol. Chem., 1922, lii, 263. A Method for the Determination of Small Amounts of Lactic Acid.

17. Friedemann, T. E., Cotonio, M., and Shaffer, P. A., J. Biol. Chem., 1927, Ixxiii, 335. The Determination of Lactic Acid.

18. Hill, A. V., Physiol. Rev., 1932, xii, 56. The Revolution in Muscle Physiology.

19. Owles, W. H., J. Physiol., 1930, 1xix, 214. Alterations in the Lactic Acid Content of the Blood as a Result of Light Exercise and Associated Changes in the $\mathrm{CO}_{2}$-Combining Power of the Blood and in the Alveolar $\mathrm{CO}_{2}$ Pressure.

20. Himwich, H. E., Yale J. Biol. and Med., 1932, iv, 259. The Role of Lactic Acid in the Living Organism. 